\title{
Studies of the Old Romanian Apple Varieties Involved in New Breeding Programs for Resistance to Venturia inaequalis
}

\author{
${\text { Ligia } \operatorname{Ion}^{1} \& \text { Liliana Badulescu }}^{1}$ \\ ${ }^{1}$ University of Agronomic Sciences and Veterinary Medicine of Bucharest, Bucharest, Romania \\ Correspondence: Ligia Ion, University of Agronomic Sciences and Veterinary Medicine of Bucharest, Romania, \\ 59 Marasti, Bucharest 011464, Romania. Tel: 40-744-69-3317. E-mail: ionnagyligia@yahoo.fr
}

Received: February 16, 2015 Accepted: April 6, 2016 Online Published: April 15, 2016

doi:10.5539/jas.v8n5p132 URL: http://dx.doi.org/10.5539/jas.v8n5p132

\begin{abstract}
Breeding for resistance to Venturia inaequalis has become a major objective for many research laboratories. The use of resistant cultivars reduces production costs for apple species. This work is focused on the identification of other sources of resistance to Venturia inaequalis among the old Romanian varieties in Transilvania area ("Turnu", "Venchi", "Vanatori 48", "Sângeriu", "Costat de Albesti" varieties), on the studies of the quality of these varieties, the use of the most valuable of them in the Romanian breeding program and the screening of the hybrid progenies after artificial infection with Venturia inaequalis for a durable resistance to this important apple disease. Some older Romanian varieties: "Mohorât", "Vieşti" and "Nobile de Geoagiu" were used like genitors in USAMVB's breeding program.

To identify specific resistance and develop the new plant material is important in this process. Using the domestic apple varieties well adapted to the climate in Romania in the breeding program can be an interesting premise on inducing natural genetic resistance to Venturia inaequalis. After artificial infection we observed that a number of varieties such as "Prescurate", "Turnu", "Venchi", "Gurguiate", "Rosu Marin" and "Sângeriu" showed some genetic resistance to Venturia inaequalis, falling within Class 0. In total there were 36 plants belonging to class 0 which means no symptoms. In Class 1, 550 plants were assigned, which is also considered resistant. The results are presented in Table 3 and in Figure 6. The variety which recorded the highest values was "Iridium" with 139 plants, followed by the variety "Rosu Marin" with 124 plants and "Venghi" with 123 young plants.
\end{abstract}

Keywords: old apple, phenotyping, resistence, screening, varieties

\section{Introduction}

The fungus Venturia inaequalis causes apple scab (Bénaouf et al., 1998), the most widespread diseases of apple trees (Tenzer \& Gessler, 1997). Leaves attacked by scab have a lower assimilation rate (Bowen et al., 2001). They are falling off earlier, fruits do not develop to normal size and do not have the full taste quality (Dvořák et al., 1976). Breeding for resistance is one of the effective measures for a protection against this disease. Crosby et al. (1992) describe two basic types of resistance of apple trees to scab disease. The first is qualitative (monogenic) resistance that is typical of some species of the genus Malus. Segregation of susceptible and resistant progenies is guided by Mendel's laws (Hugh et al., 1953). An important source of this resistance is Malus floribunda Sieb. clone 821. Prima was the first resistant variety that was bred with a $V f$ gene (Dayton et al., 1970). Simultaneously with the development of apple resistance to scab new races of Venturia inaequalis were also found (Parisi et al., 1993, Bénaouf et al., 2000). Several techniques are available for controlling scab. Advantages of one method over another depend on the number of trees you are managing and whether conditions are ideal for disease development (Bogya, 1999). Fruit breeding is very time-consuming and costly. It takes at least 20 years from the first crossing to a commercial apple cultivar (Becker et al., 1990). The flower is emasculated and pollen from a known parent (father) is transferred. The selection of parents is very important. The flower is protected in a small bag after the pollination and later the fruit is collected (Carisse, 2000). The next season the seeds are sown, and thereafter selection is made among the seedlings. The juvenile period is long, at least 4 years and sometimes up to 7-8 years. Sometimes backcrossing is necessary to obtain the right characteristics. If the desired trait is under polygenic control, there will be a variation range. In this case a progeny of several thousands of seedlings would only yield one seedling with a combination of these characters 
(Janick \& Moore, 1996).

Fruit quality (size, shape, colour, taste, aromatics, russet, acidity, sugar content, firmness etc.), winter hardiness, pest and disease resistance and tree architecture are important traits. In the final analysis, factors such as flavour and texture could mean failure or success of a new variety on the market. Breeding for industrial purposes is not so common apart from the cider industry. Breeding for disease resistance is becoming increasingly important, in particular for organic growing, and that is discussed in more detail below (Carisse et al., 2000). Other future breeding strategies could involve using marker assisted selections as a tool. The implementation of resistance from apple varieties of Romanian origin could be a promising way for a viable breeding program in Romania. The first step in this work was the identification, collection (from different parts of the country) and evaluation of a number of important old local varieties (Brown, 1992). In the Romanian breeding program recovery of the old local apple varieties that are best accommodated to the climatic conditions of Romania, was used like a natural source of resistance to pathogen attacks. The purpose of this paper is to carry out a screening of the resistance to Venturia inaequalis) in some local varieties of apple.

\section{Method}

\subsection{Plant Material}

The study was carried on 20 apple cultivars (Table 1), collected in 2014 in different privacy orchards for Transilvania, Romania (varieties "Turnu", "Venchi”, "Vanatori 48", "Sangeriu”, "Costat de Albesti” etc.) (Figure $1)$.

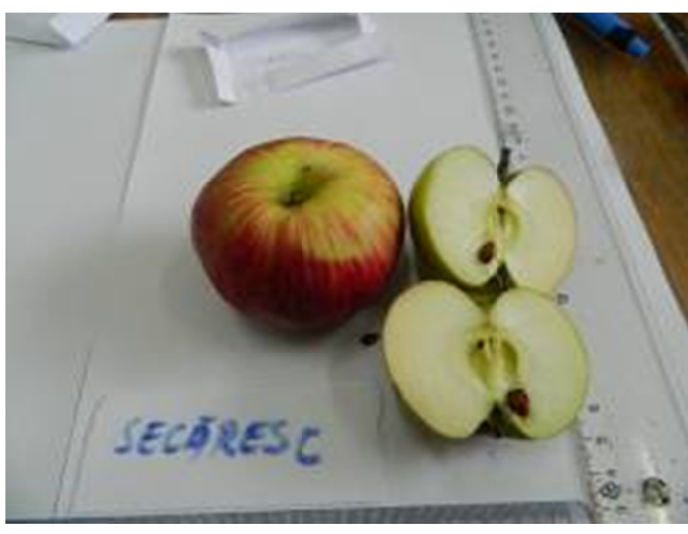

Săsesc

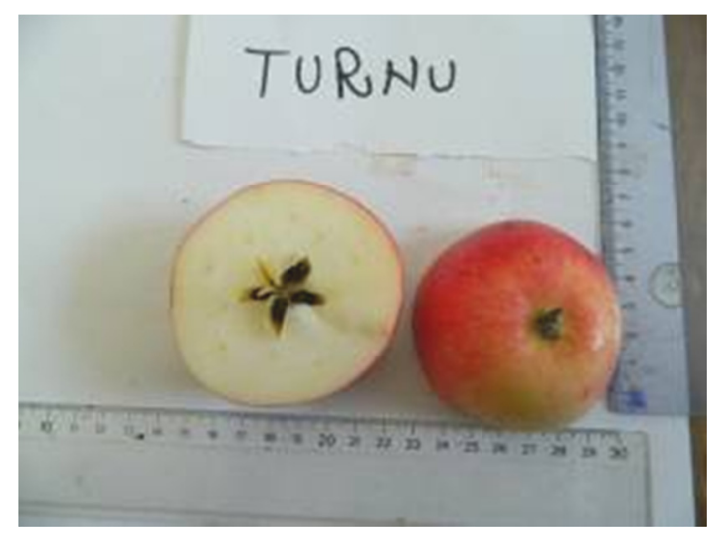

Turnu

Figure 1. The apple varieties "Săsesc" and "Turnu"

The rootstock used was MM 106 and the trees were planted at $4.5 \times 2.0 \mathrm{~m}$ (1110 trees/hectare); five trees for each cultivar, there were three replicates. For the quality of fruits, 5 mature fruits were sampled for each variety.

Concerning the phenotyping tests made from the old varieties and also for the new progenies obtained by using some of these varieties like genitors in a breeding program. The response of cultivars to the scab attack was assessed in the artificial conditions of infection.

$>$ Inoculum was prepared in the laboratory according to protocol (Chevalier et al., 2004);

$>$ Artificial infections were done in the greenhouse by spraying fine young seedlings in the 4-5 true leaf stage;

> The lecture was made 14 days after infection, where each hybrid based on the symptoms presented was placed in classes of resistance, starting from class 0 to class 4 with subunit 3a, 3b and 3c (Chevalier et al., 2004).

\subsection{Methods}

\subsubsection{The Specific Weight}

The specific weight depends on the composition and structure of the fruit.

In general, the products rich in dry substance and with a dense structure, low in the air, have higher bulk densities, and vice versa. The specific weight or density (d) means the ratio of weight and volume $(\mathrm{d}=\mathrm{G} / \mathrm{V})$. For this method, 5 mature fruits of each variety were sampled and the average weight of the five fruits were used. 


\subsubsection{Soluble Dry Matter}

Soluble dry matter is the most important part of total dry matter. It is determined by refractometer. For this method, $5 \mathrm{~g}$ fruit mesocarp probes were sampled for each variety, mashed in order to obtain the juice. The reading was made by refractometer.

\subsubsection{The Content of Vitamin C}

The HPLC analysis was carried out to determine the vitamin C and organic acids on a Shimadzu class LC VP HPLC system with class LC-VP software, a pump (LC-6AD), and a UV-VIS detector (SPD-10AV VP). The columns used were YMC Pack-ODS $(250 \mathrm{~mm} \times 4.6 \mathrm{~mm}$ I.D., $5 \mu \mathrm{m})$ for organic acids and SGE $(250 \mathrm{~mm} \times 4.6$ $\mathrm{mm}$ I.D., $5 \mu \mathrm{m}$ ) for vitamin C. The mobile phases were water adjusted to $\mathrm{pH} 2.2$ with trifluoroacetic acid (organic acids) and to $\mathrm{pH} 3$ with phosphoric acid (vitamin C). Separation was carried out by isocratic elution with a flow rate of $0.4 \mathrm{ml}$ min- 1 and column temperature was ambient. The UV detector was set at $210 \mathrm{~nm}$ and $254 \mathrm{~nm}$, respectively. The quantity was based on the peak area measurement.

Sample $(10 \mathrm{~g})$ was extracted in $10 \mathrm{ml}$ water adjusted to $\mathrm{pH} 1.5$ with trifluoroacetic acid for organic acids and with $10 \mathrm{ml}$ phosphoric acid-water $(2 \%, \mathrm{v} / \mathrm{v})$ for vitamin $\mathrm{C}$. The extracts were filtered through filter paper. Then, $1.5 \mathrm{ml}$ buffer $\left(0.01 \mathrm{M} \mathrm{KH}_{2} \mathrm{PO}_{4}, \mathrm{pH} 8.0\right)$ was added to $1.5 \mathrm{ml}$ sample extract. From this, $1.5 \mathrm{ml}$ (organic acids) and $1 \mathrm{ml}$ (vitamin $\mathrm{C}$ ) of these mixtures were loaded on to $\mathrm{C} 18$ cartridges. After loading, $3 \mathrm{ml}$ water adjusted to pH 1.5 with trifluoroacetic acid for organic acids and $2 \mathrm{ml}$ phosphoric acid-water $(2 \%, \mathrm{v} / \mathrm{v})$ for vitamin $\mathrm{C}$ were passed through the cartridges. For HPLC, $20 \mu \mathrm{l}$ of the eluents were injected.

\section{Results}

\subsection{The Specific Weight}

Table 1 presents the weight of apples mentioned in the study (Figure 2). Largest fruit weight was recorded for variety "Renet Portocaliu" with $165.47 \mathrm{~g}$, followed by variety "Turnu" with $158.70 \mathrm{~g}$ and "Venchi" variety with $156.45 \mathrm{~g}$. The fruits that recorded the lowest weight $73.37 \mathrm{~g}$ are from the variety Prescurate".

Table 1. Results on apple fruit weight and content in soluble solids

\begin{tabular}{llll}
\hline No.crt & Variaties & S.U. $(\%)$ & Weight $(\mathbf{g})$ \\
\hline 1. & Roșu Marin & $19.0^{\mathrm{CT}}$ & $120.2^{\mathrm{CT} \mathrm{T}^{*}}$ \\
2. & Florina & $12.6^{000^{*}}$ & $132.6^{\mathrm{xxx^{* }}}$ \\
3. & Coadă scurtă & $20.6^{\mathrm{xxx}}$ & $144.5^{\mathrm{xxx}}$ \\
4. & Necunoscutul & $16.1^{000}$ & $123.7^{\mathrm{N}}$ \\
5. & Andrifișer & $17.6^{000}$ & $88.2^{000}$ \\
6. & Prescurate & $15.2^{000}$ & $73.3^{000}$ \\
7. & Renet Portocaliu & $18.7^{\mathrm{N}}$ & $165.4^{\mathrm{xxx}}$ \\
8. & Vânatori 48 & $13.2^{000}$ & $91.2^{000}$ \\
9. & Rosiori Călugărești & $15.8^{000}$ & $105.3^{000}$ \\
10. & Iridium & $14.1^{000}$ & $135.4^{\mathrm{xxx}}$ \\
11. & Microsu & $17.8^{00}$ & $86.0^{000}$ \\
12. & Costat de Albești & $13.3^{000}$ & $155.9^{\mathrm{xxx}}$ \\
13. & Domnesc & $11.4^{000}$ & $113.1^{000}$ \\
14. & Sângeriu & $11.8^{000}$ & $130.6^{\mathrm{xxx}}$ \\
15. & Venchi & $17.2^{000}$ & $156.4^{\mathrm{xxx}}$ \\
16. & Calvil alb & $13.2^{000}$ & $121.3^{\mathrm{N}}$ \\
17. & Varga & $14.0^{000}$ & $96.1^{000}$ \\
18. & Sălciu & $12.9^{000}$ & $119.5^{\mathrm{N}}$ \\
19. & Turnu & $13.7^{000}$ & $158.7^{\mathrm{xxx}}$ \\
20. & Gurguiate & $12.6^{000}$ & $117.5^{\mathrm{N}}$ \\
\hline
\end{tabular}

Note. DL 5\% - 0.75\% - 3.88 g; DL 1\% - 1.01\% - 5.21 g; DL 0.1\% - 1.34\% - $6.86 \mathrm{~g}$.

* Statistics analysis using the significant variation method values:

$\mathrm{x}$ : significant positive; 0 : significant negative; $\mathrm{xx}$ : distinctive significant positive; 00: distinctive significant negative; $x x x$ : very significant positive; 000 : very significant negative; N: neutral. 
The variety "Rosu Marin" was considered the control sample (CT). From statistic point of view the differences concerning the content of soluble solids have been statistically assured like very significant positive for the variety "Coadă Scurtă". Excepting the variety "Renet Portocaliu" all the others were significant negative. Concerning the weight of the fruits the variability was bigger than the variety " Rosu Marin" for the varieties: "Renet Portocaliu", "Iridium", "Costat de Albești", "Sângeriu", "Venchi", "Turnu" the fruits were bigger, the differences have been statistically assured like very significant positive (xxx) and the lower values for the varieties: "Andrifișer", "Prescurate", "Vânatori 48”, "Rosiori Călugărești", "Microsu”, "Domnesc", "Varga" the differences have been statistically assured like very significant negative (000).

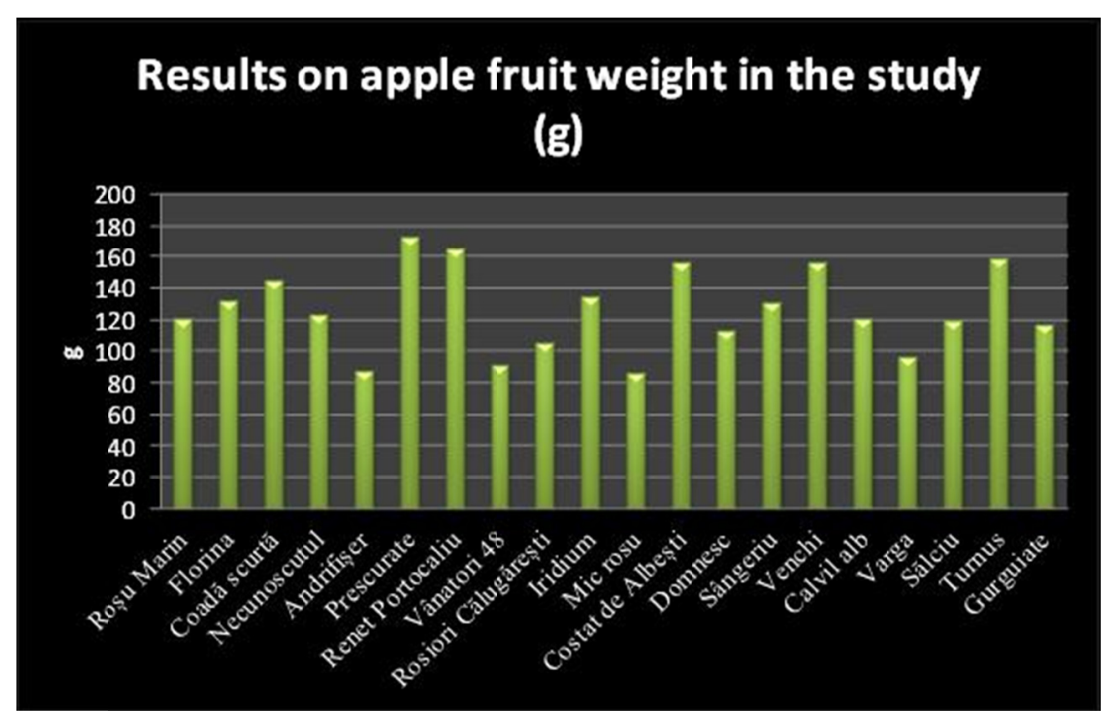

Figure 2. Results on apple fruit weight in the study

Figure 2 shows the results of spatial apple fruit weight, and noticed that most fruits kept their weight around the average.

\subsection{Determination of Soluble Dry on Studied Apple Varieties}

Soluble dry matter is the most important part of total dry matter. In its composition, there are numerous chemical components with great value food and water soluble micromolecular (simple carbohydrates, minerals, acids, vitamins, etc.), largely accumulated in the cell vacuole juice. Permanent components, best represented are sugars (fructose, glucose and sucrose) that can hold $30-80 \%$, but frequently more than $50 \%$ soluble dry matter.

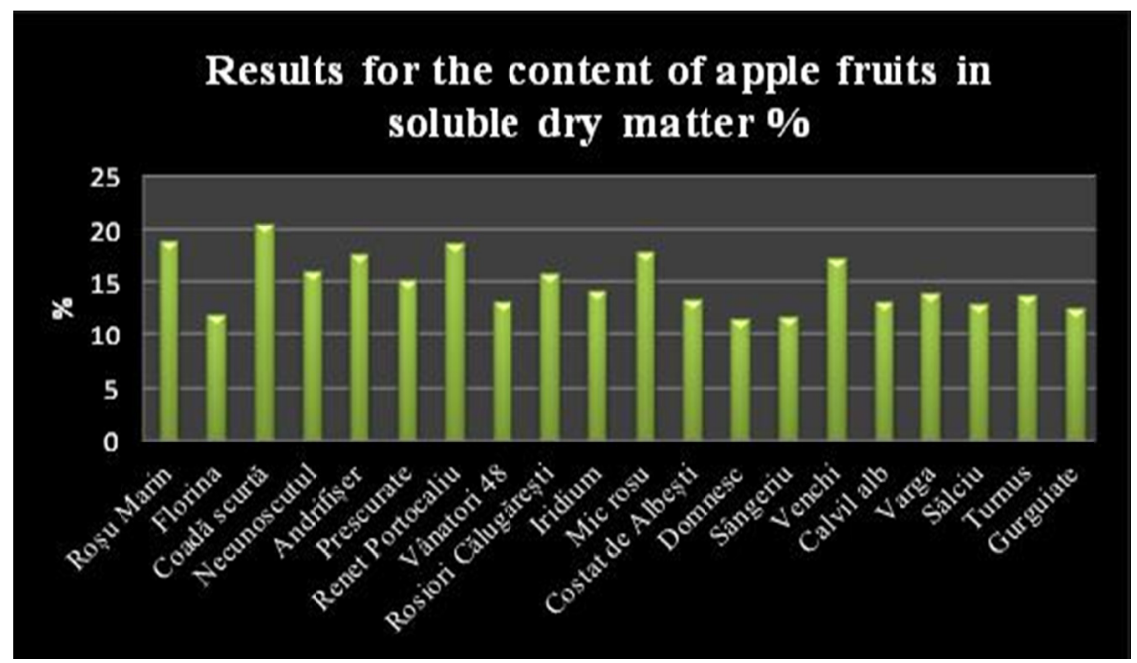

Figure 3. Results for the content of apple fruit in soluble dry matter (\%) 
Regarding the content of fruit soluble dry matter (Figure 3) it is observed that the highest values are registered by the variety "Coadă scurtă" with $20.6 \%$, followed by cultivar "Roșu Marin" with $19.0 \%$, "Renet Portocaliu" with $18.7 \%$ (Table 1). The weakest value was recorded by the variety 'Domnesc' with $11.4 \%$. In conclusion, for the majority of varieties the taste is acidic, except the varieties mentioned above.

\subsection{The Content of Vitamin C}

In terms of content of vitamin C for apple varieties studied in 2014 the results are presented in Figure 4 . Three determinations were carried out approximately every 10 days. The fruits were stored at $4{ }^{\circ} \mathrm{C}$. It is observed that as the fruit progresses throughout their retention drops sharply vitamin $\mathrm{C}$ every 10 days. The highest value in terms of content in vitamin $\mathrm{C}$ was recorded by the variety 'Andrifişer' with $36,63 \mathrm{mg} / 100 \mathrm{~g}$ pp, followed by cultivar "Iridium" with $36.37 \mathrm{mg} / 100 \mathrm{~g} \mathrm{pp}$.

The worst value was recorded by the variety "Gurguiate" with $13.45 \mathrm{mg} / 100 \mathrm{~g} \mathrm{pp}$. These values were recorded during storage on February 20, 2014, the Figure 4.

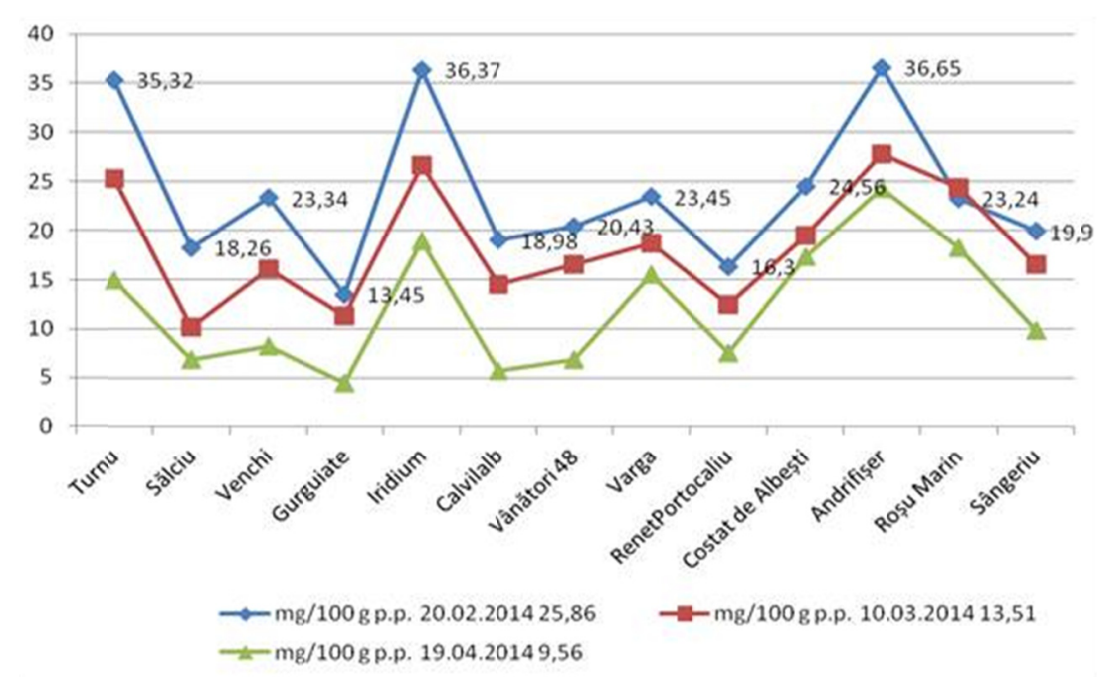

Figure 4. Results on the content of vitamin C among old apple varieties in 2014

After an interval of 10 days from 10/03/2014 highest value was recorded by the variety "Andrifişer" with 27.87 $\mathrm{mg} / 100 \mathrm{~g}$ pp followed by "Iridium" with $26.65 \mathrm{mg} / 100 \mathrm{~g} \mathrm{pp}$, “Turnu” with $25.36 \mathrm{mg} / 100 \mathrm{~g}$ pp, and the variety "Rosu Marin" with $24.43 \mathrm{mg} / 100 \mathrm{~g}$ pp (Figure 4).

20 days after first determining, the values drastically decreased, however, approximately the same correlation between studied varieties was maitained, so with the greatest value is variety 'Andrifişer' with $24.32 \mathrm{mg} / 100 \mathrm{~g}$ pp (Figure 4).

The determinations demonstrated that the vitamin $C$ content of some varieties had not greatly decreased as the variety "Andrifişer" or "Rosu Marin", "Iridium" and "Turnu" (Figure 4) which showed a good capacity for storage.

\subsection{Involvement of Old Varieties in the Breeding Process}

Some of the old Romanian apple varieties ("Mohorât", "Nobile Geoagiu", "Viești") were involved in the new breeding program like genitors $\left({ }^{\lambda}\right)$ for resistance to the scab in order to obtain the interesting plant material (progenies) for the next studies. 
Table 2. Results on the number of binding fruits and seeds obtained on October 13, 2014

\begin{tabular}{|c|c|c|c|c|c|}
\hline No. Crt & $\begin{array}{l}\text { The hybrid } \\
\text { combinations-varieties }\end{array}$ & $\begin{array}{l}\text { Number of seeds } \\
\text { harvested }\end{array}$ & $\begin{array}{l}\text { Number of } \\
\text { fruit harvested } \\
\text { on } 12 / 10 / 2014\end{array}$ & $\begin{array}{l}\text { Number of fruits } \\
\text { on } 05 / 05 / 2014\end{array}$ & $\begin{array}{l}\text { Number of pollinated } \\
\text { flowers } 14 / 04 / 2014\end{array}$ \\
\hline 1. & $\mathrm{C} 1-$ Florina $\stackrel{+}{\times} \times$ Mohorât $^{\wedge}$ & 7 & 5 & 115 & 342 \\
\hline 2. & C2 - Idared $Q \times$ Mohorât $\widehat{ }{ }^{\wedge}$ & 0 & 0 & 89 & 352 \\
\hline 3. & C3 - Florina $q \times$ Nobile Geoag $\widehat{\supset}$ & 7 & 6 & 104 & 306 \\
\hline 4. & $\mathrm{C} 4$ - Idared $q \times$ Nobile Geoag $\overbrace{}^{\lambda}$ & 0 & 0 & 108 & 382 \\
\hline 5. & C5 - Romus $\odot \times$ Viești $\widehat{\supset}$ & 17 & 5 & 172 & 344 \\
\hline 6. & 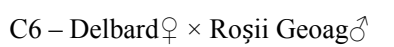 & 16 & 9 & 70 & 162 \\
\hline
\end{tabular}

Table 2 presents the results of the number of fruits on October 12, 2014 at the hybrid combinations studied, so the best value was recorded in the hybrid combination "Delbard $\times$ Roșii de Geoagiu" with 9 fruits, followed by combination "Florina $\times$ Nobile Geoagiu" with 6 fruits, "Florina $\times$ Mohorât" with 5 fruits and the combination "Romus $\times$ Viești" with 5 fruits. As regards the number of seeds from these fruits, the highest number of seeds was produced from the hybrid combination "Romus $\times$ Viești" with 17 seeds, followed by the combination "Delbard × Roșii de Geoagiu" with 16 seeds.

These results demonstrate that even though a large number of flowers was pollinated, the seed number obtained was very low, which is related to varieties compatibility and the agricultural technique applied during the growing season. Therefore the location where pollination is performed is extremely important for developments in research and achieving results.

\subsection{Results on Phenotypic Selection of Old Apple Varieties}

The seeds obtained from old native varieties were stratified and then germinated and when they reached the stage of 4-5 leaves, they were artificially infected with a strain of Venturia inaequalis, a common race in the field.

The results in terms of the number of seeds per variety obtained are shown in Table 3 . The artificial infections were made in the greenhouse according to the protocol presented by Chevalier et al. (1991). For inoculation a mix of scab races collected from the orchard was used. Young plants of 4-5 true leaves were sprayed with a conidia suspension of Venturia inaequalis CKE. They were incubated for 48 hours at $18{ }^{\circ} \mathrm{C}$ and $100 \%$ relative humidity. Symptoms on the leaves were evaluated visually (reading) at 21 days after inoculation, and the young plants were divided into 5 classes. Class 0 includes plants without visible symptoms on the leaves; Class 4 includes plants with lesions on leaves and strong sporulation (Figures 5).
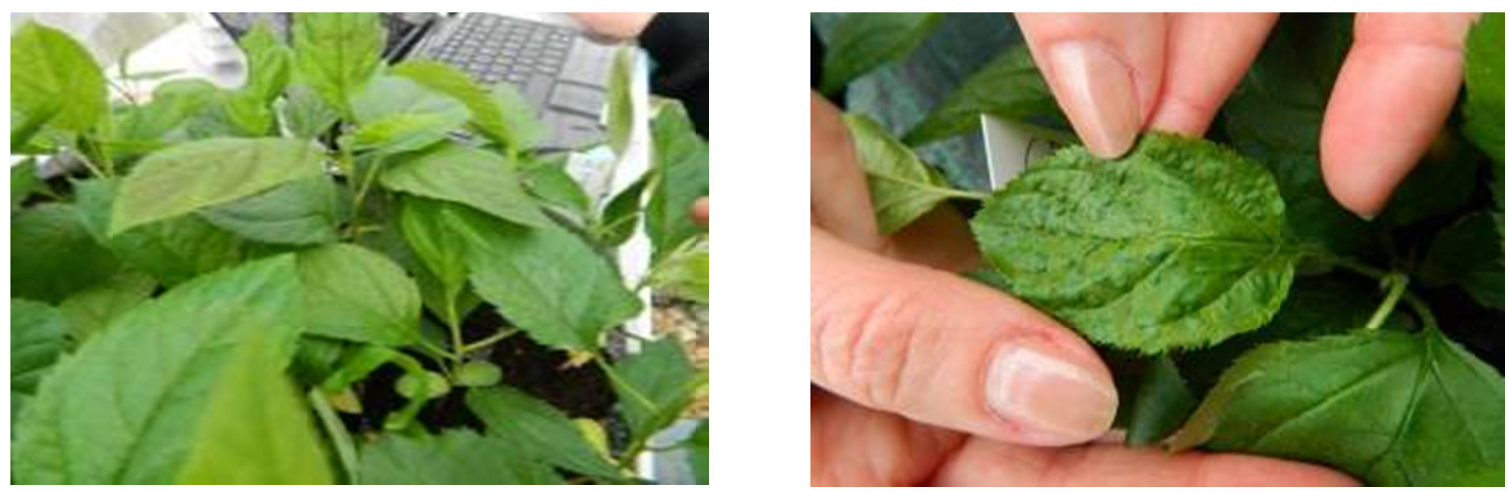

Figures 5. The symptoms of classes 4 and 5: susceptible Venturia inaequalis infection

\section{Discussion}

Using the breeding program, the domestic apple varieties well adapted to the climate in Romania can be an interesting premise on inducing natural genetic resistance to Venturia inaequalis. In this regard, scab races, the inoculation method, environmental conditions and culture and defining characters were not the same in all of 
these studies. The artificial infections in these varieties and their hybrids can provide some information on the plant defence mechanism against the pathogen agent's attack.

Support and promote the culture of the apple varieties with genetic resistance to diseases constitute, for new plantations, technological links with economic performance, with immediate effect on total or partial removal treatments with fungicides, represent the main factor in obtaining organic production.

Table 3 presents the results of the number of seeds extracted from studied apple fruits varieties. In total this study started with 2391 seeds (Figure 6). The highest number of seeds extracted and taken into study was the variety "Rosu Marin" 288 seeds, followed by the variety"Gurguiate"with 252 seeds, then the variety"Turnu" with 220 seeds.

Table 3. Results on the classification of old studied apple varieties concerning the resistance according to the classes of symptoms (Chevalier 1991)

\begin{tabular}{|c|c|c|c|c|c|c|c|c|c|c|c|}
\hline \multirow{2}{*}{$\mathrm{Nr}$ Crt. } & \multirow{2}{*}{ Varieties of apple } & \multicolumn{4}{|c|}{ Classes of symptoms } & \multirow{2}{*}{\multicolumn{2}{|c|}{$3 \mathrm{~A}$}} & \multirow{2}{*}{$3 \mathrm{~B}$} & \multirow{2}{*}{ Died } & \multirow{2}{*}{ NL } & \multirow{2}{*}{ Total seeds } \\
\hline & & 0 & 1 & 2 & 4 & & & & & & \\
\hline 1. & Prescurate & 7 & & 49 & $82^{\mathrm{CT}^{*}}$ & & 13 & 20 & 1 & 45 & $219^{\mathrm{CT}^{*}}$ \\
\hline 2. & Turnu & 2 & 2 & 66 & $86^{\mathrm{xx^{* }}}$ & & 5 & 23 & & 36 & $220^{\mathrm{N}^{*}}$ \\
\hline 3. & Sălciu & & 29 & & $25^{000^{*}}$ & & & & & 40 & $94^{000^{*}}$ \\
\hline 4. & Venchi & 2 & 123 & & $56^{000}$ & & & & & 36 & $97^{000}$ \\
\hline 5. & Gurguiate & 8 & 10 & 113 & $90^{\mathrm{xxx}}$ & & 12 & 12 & & 146 & $252^{\mathrm{xxx}}$ \\
\hline 6. & Iridium & & 139 & & $10^{000}$ & & 11 & 10 & & 13 & $183^{000}$ \\
\hline 7. & Calvil alb & 0 & 4 & 8 & $59^{000}$ & & 1 & 3 & 6 & 45 & $126^{000}$ \\
\hline 8. & Vânători 48 & 0 & 6 & 9 & $67^{000}$ & & 3 & 1 & 7 & 32 & $125^{000}$ \\
\hline 9. & Varga & 0 & 2 & 1 & $98^{\mathrm{xxx}}$ & & 2 & 1 & 5 & 34 & $143^{000}$ \\
\hline 10. & Renet Portocaliu & 0 & 0 & 0 & $78^{00}$ & & 7 & 8 & 9 & 49 & $151^{000}$ \\
\hline 11. & Costat de Albești & 0 & 0 & 0 & $98^{\mathrm{xxx}}$ & & 1 & & & 67 & $166^{000}$ \\
\hline 12. & Andrifișer & 0 & 0 & 0 & $88^{x x x}$ & & 2 & & & 45 & $135^{000}$ \\
\hline 13. & Roșu Marin & 9 & 124 & 42 & $35^{000}$ & & 32 & 9 & 1 & 36 & $288^{\mathrm{xxx}}$ \\
\hline 14. & Sângeriu & 8 & 111 & 36 & $23^{000}$ & & 12 & & & 32 & $192^{000}$ \\
\hline & Total & 36 & 550 & 324 & 865 & 2 & 101 & 87 & 29 & 584 & 2391 \\
\hline
\end{tabular}

Note. DL 5\% - 2.47 - 5.19; DL 1\% - 3.35 - 7.02; DL 0.1\% - 4.48 - 9.38.

* Statistic analysis using the significant variation method values:

$\mathrm{x}$ : significant positive; 0 : significant negative; $\mathrm{xx}$ : distinctive significant positive; 00: distinctive significant negative; xxx: very significant positive; 000: very significant negative; $N$ : neutral.

The Statistics analysis using the significant variation method values, highlights the fact that the differences between variety "Prescurate" and the others have beenstatistically assured like very significant positive ("Gurguiate", "Roșu Marin") and have beenstatistically assured like very significant negative ("Iridium", "Calvilalb", "Vânători 48", "Varga", "RenetPortocaliu", "Andrifișer".

Table 3 presents the classes of resistance to scab in this order: Class 0 means no symptoms (resistant genotypes), class 1 means very low symptoms on the leaves, class 2 with the mild symptoms on leaf ribs (also resistant genotypes); class 3 is divided into 3A and 3B (start to be susceptible) and class 4 (susceptible).

Change of the assortment at shorter time intervals is required by increasing susceptibility to diseases and pests in some apple varieties, the emergence of new varieties showing superior qualities of existing varieties, adaptation to new crop technologies and systems, adapting assortment climate changes-resistance or tolerance to climatic stress factors. 


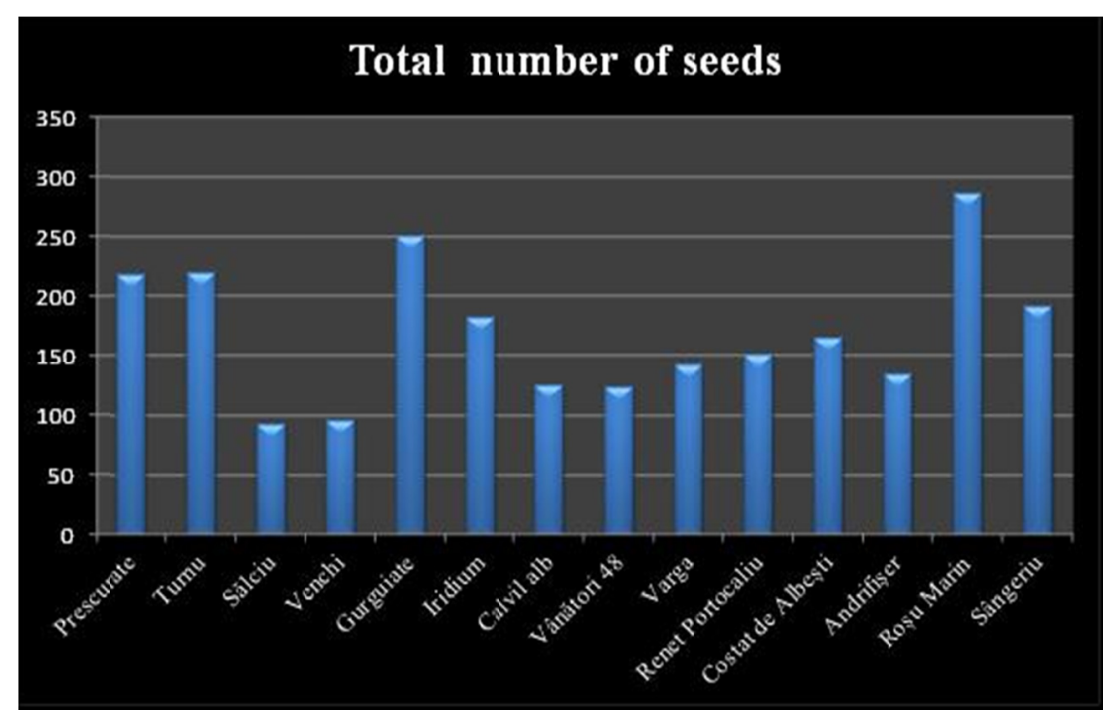

Figure 6. Results on the total number of seeds of the varieties of apples studied

After artificial infection we observed that a number of varieties such as "Prescurate,"“Turnu", "Venchi", "Gurguiate", "Rosu Marin" and "Sângeriu" showed some genetic resistance to Venturia inaequalis, falling within Class 0. In total 36 plants showed as belonging to class 0 (which means no symptoms).

In Class 1, also considered resistant 550 plants were assigned, the results are presented in Table 3 and in Figure 6 . The variety which recorded the highest value was "Iridium" with 139 plants, followed by the variety "Rosu Marin" with 124 plants and "Venghi" with 123 young plants.

\section{Conclusions}

Scab, caused by the fungus Venturia inaequalis is one of the most damaging diseases of apple in Romania. There is a wide variability of reaction to scab attacks in 20 apple varieties tested during two years. From a statistic point of view the differences concerning the content of soluble solids have beenstatistically assured, as very significant positive for the variety "CoadăScurtă". Except the variety "RenetPortocaliu," all the others were significant negative. Concerning the weight of the fruits the variability was bigger than with the variety "Rosu Marin." For the varieties: "RenetPortocaliu", "Iridium", "Costat de Albești", "Sângeriu", "Venchi", "Turnu" the fruits were bigger, the differences have beenstatistically assured a very significant positive (xxx) and the lower values for the varieties: "Andrifișer", "Prescurate", "Vânatori 48", "RosioriCălugărești", "Microsu", "Domnesc", "Varga" the differences have beenstatistically assured as very significant negative (000).

Regarding the content of fruit soluble dry matter (Figure 3) it is observed that the highest values are registeredby the variety "Coadăscurtă" with $20.6 \%$.

The highest value in terms of vitamin C content was recorded by the variety 'Andrifişer' with 36, $63 \mathrm{mg} / 100 \mathrm{~g}$ pp, followed by cultivar "Iridium" with $36.37 \mathrm{mg} / 100 \mathrm{~g}$ pp.

The determinations demonstrated that the vitamin $\mathrm{C}$ content of some varieties have not greatly decreased as the variety "Andrifişer" or "Rosu Marin", "Iridium" and "Turnu“(Figure 4) which showed a good capacity forstorage.

Some of the old Romanian apple varieties ("Mohorât", "Nobile Geoagiu", "Viești") were involved in new breeding program like genitors $\left({ }^{\Uparrow}\right)$ for resistance to scab in order to obtain the interesting plant material (progenies) for the next studies.

These results demonstrate that even though there was a large number ofpollinated flowers, the number of seeds obtained was very low, which is related to the compatibility of the varieties and agricultural technique applied during the growing season. Therefore the location where pollination is performed is extremely important for developments in research and achieving results.

Concerning the phenotypic test, after artificial infection we observed that a number of varieties such as "Prescurate", "Turnu", "Venchi", "Gurguiate", "Rosu Marin" and "Sângeriu" showed some genetic resistance to Venturia inaequalis, falling within Class 0 . In total there were 36 plants belonging to class 0 (which means no 
symptoms).

In Class 1, also considered resistant 550 plants were assigned, the results are presented in Table 3 and in Figure 6. The variety which recorded the highest value was "Iridium" with 139 plants, followed by the variety "Rosu Marin" with 124 plants and "Venghi"with 123 young plants.

\section{References}

Becker, C. M., \& Burr, T. J. (1990). Apple scab lesions, caused by Venturia inaequalis, on shoots in New York; histology an enumeration of inoculum. Phytopathology, 80, 117.

Bénaouf, G., \& Parisi, L. (1998). Characterization of Venturia inaequalis pathogenicity on leaf discs of apple trees. European Journal of Plant Pathology, 104, 785-793. http://dx.doi.org/10.1023/A:1008616728248

Bénaouf, G., \& Parisi, L. (2000). Genetics of host-pathogen relationships between Venturia inaequalis races 6 and 7 and Malus species. Phytopathology, 90, 236-242. http://dx.doi.org/10.1094/PHYTO.2000.90.3.236

Bogya, S. (1999). Spiders (Aranae) as polyphagous natural enemies in orchard (Thesis, Wageningen, The Netherlands).

Bowen, J. K., Mesarich, C. H., Bus, V. G., Beresford, R. M., Plummer, K. M., \& Templeton, M. D. (2001). Venturia inaequalis: The causal agent of apple scab. Mol. Plant Pathology, 12(2), 105-22. http://dx.doi.org/10.1111/j.1364-3703.2010.00656.x

Brown, S. (1992). Genetics of apple. In J. Janick (Ed.), Plant breeding reviews (Vol. 9, pp. 333-366). http://dx.doi.org/10.1002/9780470650363.ch9

Carisse, O. (2000). 50 years of research on biological control. Integrated Control of Pome Fruits. IOBC wprs Bulletin, 23(12), 5-10.

Carisse, O., Svircev, A., \& Smith, R. (2000). Integrated biological control of apple scab. Integrated Control of Pome Fruits. IOBC wprs Bulletin, 23(12), 23-28.

Chevalier, M., Lespinasse, Y., \& Renaudin, S. (1991). A microscopic study of different classes of symptoms coded by the $V f$ gene in apple for resistance to scab (Venturia ineaqualis). Plant Pathology, 40, $249-256$. http://dx.doi.org/10.1111/j.1365-3059.1991.tb02374.x

Crosby, J. A., Janick, J., Pecknold, P. C., Korban, S., O’Connor, P. A., Ries, S. M., ... Voordeskers, S. (1992). Breeding apples for scab resistance 1945-1990. Acta Hort, 317, 43-70. http://dx.doi.org/10.17660/ActaHortic.1992.317.5

Dayton, D. F., Mowry, J. B., Hough, L. F., Balley, C. H., Williams, E. B., Janick, J., \& Emerson, F. H. (1970). Prima - An early fall red apple with resistance to apple scab. Fruit Var Hort Dig, 24, 20-22.

Dvořák, A., Vondráček, J., Kohout, K., \& Blažek, J. (1976). Jablka. Academia, Praha.

Hugh, L. F., Shay, J. R., \& Dayton, D. F. (1953). Apple scab resistance from Malus floribunda Sieb. Proc Am Soc Hortic Sci, 62, 341-347.

Janick, J., \& Moore, J. N. (Eds.). (1996). Fruit breeding. Tree and Tropical Fruits (Vol I, pp. 1-77). John Wiley \& Sons, Inc., New York, USA.

Parisi, L., Lespinasse, Y., Guilaumes, J., \& Kruger, J. (1993). A new race of Venturia inaequalis virulent to apples with resistance to the Vf gene. Phytopathology, 83, 533-537. http://dx.doi.org/10.1094/Phyto-83-533

Saghai-Maroof, M. A., Soliman, K. M., Jorgensen, R. A., \& Allard, R. V. (1984). Ribosomal DNA spacer-length polymorphism in barley: Mendelian inheritance, chromosomal location and population dynamics. Proc Nat Acad Sci, 81, 8014-8019. http://dx.doi.org/10.1073/pnas.81.24.8014

Tenzer, I., \& Gessler, C. (1997). Subdivision and genetic structure of four populations of Venturia inaequalis in Switzerland. Eur J. Plant Pathol, 103, 565-571. http://dx.doi.org/10.1023/A:1008636913211

\section{Copyrights}

Copyright for this article is retained by the author(s), with first publication rights granted to the journal.

This is an open-access article distributed under the terms and conditions of the Creative Commons Attribution license (http://creativecommons.org/licenses/by/3.0/). 